\title{
Influence of a New Energy-Saving Drying Method on the Quality of Corn Seeds
}

\author{
Kyrpa Mykola ${ }^{1}$, Kulyk Victor ${ }^{1,}$,, Kupar Julia ${ }^{1}$, Stasiv Oleg ${ }^{2}$ \\ ${ }^{1}$ State Establishment Institute of Grain Crops of National Academy Agrarian Sciences of Ukraine, Dnipro, Ukraine \\ ${ }^{2}$ Institute of Agriculture of the Carpathian Region of NAAS, Obroshino, Ukraine
}

\section{Email address:}

kylik9379992@ukr.net (K. Victor)

*Corresponding author

\section{To cite this article:}

Kyrpa Mykola, Kulyk Victor, Kupar Julia, Stasiv Oleg. Influence of a New Energy-Saving Drying Method on the Quality of Corn Seeds. American Journal of Agriculture and Forestry. Vol. 9, No. 1, 2021, pp. 1-6. doi: 10.11648/j.ajaf.20210901.11

Received: December 16, 2020; Accepted: December 23, 2020; Published: January 12, 2021

\begin{abstract}
Drying corn, especially seeds in cobs, requires much higher energy consumption compared to other cereals. Therefore, there is a need to find and study new methods of energy saving. Our work's objective was: to analyze energy-saving methods of drying corn seeds in chamber corn dryers; to investigate the effect of a new corn cobs drying method on the sowing and yield properties of seeds. The new method is energy-saving and based on the use of a SKP chamber corn dryer in combination with a heat generator for biomass burning. We researched and characterized the known energy saving methods in the process of drying in SKP type chamber corn dryers, such as: two-stage drying of cobs with additional drying in grain; return of spent coolant to the drying zone (recirculation); application of maximum allowable heating temperatures (intensive drying). We established the influence of energy-saving drying methods on the quality of corn seeds. To study the effect of the new drying method on the technological, sowing and yield properties of corn seeds, we used a typical chamber dryer for corn SKP-10 in combination with a heat generator TPG-1/25 for biomass combustion. During the drying process on the energysaving complex, cob samples were taken to determine the quality of seeds. The control level was seeds dried in a laboratory dryer at a temperature of $39^{\circ} \mathrm{C}$ with forced air circulation and indoors at a temperature of $20-25^{\circ} \mathrm{C}$. Moderate drying temperature, what provide a new energy-saving complex, reduces seed injury by thermal cracking, which is from 2 to $5 \%$. Sowing qualities and yield properties of corn seeds dried in the new complex were at the control level, and in some cases exceeded it. Thanks to the use of a new method of drying, you can completely abandon the expensive traditional fuel, while offering high technological properties and seed quality.
\end{abstract}

Keywords: Heat Generator, Chamber Corn Dryer, Cobs Drying, Seed Quality, Energy Saving Complex, Seed Germination

\section{Introduction}

Drying of seed corn requires much higher energy consumption compared to other grains, which is due to the peculiarity of its structure, namely the strong shell and deep embryo $[1,2]$.

This process determines the reduction of seed moisture to a safe dry state without loss of quality, its resistance to storage and cost $[3,4]$.

Therefore, the need to find and create new energy-saving drying methods is one of the current problems of post-harvest processing of seed corn in cobs $[5,6]$.

The problem is exacerbated by the fact that such drying must be carried out in special chamber corn dryers, at relatively low temperatures, which do not allow injury to the seeds [7-9].

The main regulated method of drying corn seeds is carried out in chamber dryers and requires significant energy consumption due to special conditions [10].

Its technical and technological parameters are as follows: temperature regime of $35-50^{\circ} \mathrm{C}$ depending on the cobs moisture, sequential starting of chambers in operation, noncyclic drying schedule, reversal, i.e. change in the direction of drying chambers purging [11].

Taking into account the noted parameters, we set the norm of conventional fuel consumption to $3,36 \mathrm{~kg}$ per one ton-percent of moisture, or up to $20 \mathrm{~kg}$ per planned ton. 
Calculations show that at this standard rate, the technical performance of the chamber dryer will be as follows: the energy consumption required to evaporate $1 \mathrm{~kg}$ of moisture is $8.56 \mathrm{MJ}$, and the thermal coefficient of performance efficiency is $30-35 \%$ of the theoretically possible values; and $55-60 \%$ in relation to the best samples of mine grain dryers. [12].

The problem of energy saving in the process of corn seeds drying becomes increasingly important due to the constant cost increase for all traditional types of energy resources diesel oil, liquefied and gaseous fuel, electricity. The problem is exacerbated by the fact that corn seed production is gradually moving to more humid regions, where better hydrothermal growing conditions are developed, but the grain is harvested too wet and requires mandatory drying.

To date, there are various technical and technological techniques aimed at energy savings in corn cobs drying, they include: two-stage drying of cobs with additional drying in the grain [13], return of spent coolant to the drying zone (recirculation) [14]; application of maximum allowable grain heating temperatures $[15,16]$ (Table 1$)$. However, not all energy-saving methods provide the main technical and technological condition of drying - maintaining high seed quality.

Table 1. Technical and technological methods of energy saving when drying corn seeds.

\begin{tabular}{lll}
\hline Drying method & Savings of traditional fuels, \% & Modernization \\
\hline Two-stage (cobs+grain) & $25-29$ & Additional dryer \\
Recirculation of heat & $20-26$ & Reconstruction \\
Use of max. allowable temperatures & $18-24$ & Reconstruction \\
With biomass combustion & 100 & New heat generator \\
\hline
\end{tabular}

All methods require some modernization and additional equipment for chamber corn dryers. It is established that due to the corn dryer modernization it is possible to achieve traditional fuels savings within 18-29\%. Among the above energy saving methods the two-stage drying requires the highest costs: additional dryer installation is needed for drying corn in grain and mild temperatures should be maintained. Techniques that have a positive effect on reducing energy consumption include: sealing the dryers; the maximum loads in dryer chambers; removal of selfshredding from the cobs weight.

It should be noted that all known methods of fuel economy do not involve its replacement, but are aimed only at the technical and technological modernization of dryers. A fundamentally different area of energy saving is the use of plant waste as fuel (corn cobs, straw, sunflower husks, wood chips, pellets, sawdust) and the creation of heat generators for their combustion [17].

Recently, in Ukraine and abroad, a number of different heat generators are offered for biomass burning with a capacity of $0,5-12,0 \mathrm{MW}$, but not all of them are suitable for drying seed corn in cobs. Their main disadvantage is the instability of the working coolant temperature. It is also unknown how the temperature regime develops in different places of the grain dryer. Its effect on sowing and yield properties of corn hybrids seeds, as well as their parent components has not been determined.

The objective of the research is to establish energy-saving methods for drying corn seeds in chamber corn dryers. To achieve the above we need to perform the following tasks:

1. to analyze the known methods of energy saving;

2. to establish their influence on sowing and yield properties of seeds in corn hybrids and their parent components;

3. to investigate a new method based on the use of biomass fuel;

4. to compare it with known methods.

\section{Material and Methods}

The research was carried out by conducting laboratory, field experiments to determine the quality of seeds under different drying modes. Energy-saving drying by the new method was carried out in the production conditions of State Enterprise "Dnipro" and "Agrosfera" (Dnipropetrovsk region).

In the process of drying on the energy-saving complex, cob samples were taken to determine the quality of seeds. As a control sample we used the seeds dried indoors at a temperature of $20-25^{\circ} \mathrm{C}$ (natural drying) and in a laboratory dryer at a heating temperature of $38^{\circ} \mathrm{C}$ and forced ventilation.

Regulated drying is thermal drying according to the current instructions, regulations developed for corn seeds.

\subsection{Laboratory Tests}

Sowing qualities were determined in accordance with the current standard of Ukraine SSTU 4138-2002, and additionally recommended by the Institute of Grains [18, 19]. Quality indicators such as grain and core moisture, weight of 1000 seeds, thermal fracturing, germination energy and germination by standard method and cold germination method were studied.

Grain moisture was determined by the standard method by drying the $5 \mathrm{~g}$ samples in a SESH-3M oven at a temperature of $130^{\circ} \mathrm{C}$ for 40 minutes. For corn grain with moisture content over $18 \%$, two-stage drying with pre-drying of the sample was used. In the first stage, a $20 \mathrm{~g}$ portion placed in a mesh box was dried at $105^{\circ} \mathrm{C}$ for 30 minutes. Pre-dried and weighed grain was ground and dried according to the standard method.

The 1000 seeds weight was determined by a laboratorymodified method, which differed from the standard one: two 500 seeds samples were taken and weighed with accuracy up to $0,01 \mathrm{~g}$. The weight of each sample was converted to the 1000 seeds weight and its average weight was obtained. The 
weight difference in two samples should not exceed $3 \%$ of the average weight of 1000 seeds.

Thermal and mechanical cracking were determined according to the methodology of the Institute of Agriculture of the steppe zone of NAAS (Ukraine). To do this, 100 grains from the average seed sample are taken and placed in the slots of the diaphanoscope plate. In the transmitted light of the device we counted grains with visible cracks (one or more) in the aleurone layer or solid endosperm.

\subsection{Field Research}

During the field studies methodology recommended for corn [20] was used on plots with an estimated area of $15,68 \mathrm{~m}^{2}$, in 4-fold repetition with a randomized location of plots. Field germination counts began when the seedlings were in a state of "awls" (just appeared), and their number on the site was not less than $10-15 \%$. The height of plants in the 7-8 leaves phase and after full flowering was measured. Before harvesting, the actual number of corn plants on the plot was counted.

Corn was harvested manually, to determine the structure of the crop cobs weighing $5 \mathrm{~kg}$ were taken from the first and third replicates. Weighing was performed for cobs that were collected from each replication. Cob samples were threshed, the yield and grain moisture were determined. Data was processed with mathematical, statistical methods and computer software according to known methods [21].

\section{Results and Discussions}

The literature sources analysis shows that the greatest contribution to the development of new methods of drying and energy saving techniques was made at the Institute of Grain Crops of NAAS Ukraine (formerly the All-Union Research Institute of Corn, Institute of Grain, Institute of Steppe Agriculture) and at Odessa National Academy of Food Technology. Among the energy saving techniques we distinguish the following: two-stage drying in cobs with subsequent threshing and drying in the grain; recirculation; drying at intense temperatures.

Significant energy savings can be achieved by drying corn seeds in a two-stage method; it includes drying corn cobs in SKP-6 chamber corn dryer to a grain moisture content of 20$22 \%$, cobs threshing and grain drying to a moisture content of $12-13 \%$ at mild temperatures using a mine dryer of 2DSP$32 \mathrm{OT}$ type. Two-stage drying improved technical and technological indicators, but reduced sowing and yield properties of seeds. Thus, compared to the regulated drying method laboratory germination decreased by $36 \%$, field germination $-33 \%$, and yield by $0.82 \mathrm{t} / \mathrm{ha}$.

A significant reduction in fuel consumption was observed during drying in recirculation mode. Under such conditions, the SKPM-18M corn dryer worked as follows: drying began in the normal mode, then after 25-30 hours the recirculation system was started and the working coolant movement direction was changed periodically. To ensure this process, a diffuser with a diverter valve was installed between the grain dryer and the fuel and ventilation compartment to change the coolant movement direction.

This method of drying did not have a negative impact on seed quality. On the contrary, there was an improvement in field germination compared to the traditional method of drying. Laboratory germination was unchanged at $96 \%$ for both drying methods.

When increasing the drying speed, as well as reducing the level of energy consumption, the temperature regime in the dryer is of great importance. At intensive temperatures, fuel savings are achieved by accelerating the drying process and increasing the utilization coefficient of the dryer. The control seeds were dried naturally and by the regulated method of drying. Increasing the coolant temperature up to $55^{\circ} \mathrm{C}$ did not have negative impact on the sowing and yield properties of corn seeds.

Table 2. Influence of different energy saving methods on sowing and yield properties of corn seeds.

\begin{tabular}{|c|c|c|c|c|}
\hline \multirow{2}{*}{$\begin{array}{l}\text { Energy saving } \\
\text { method }\end{array}$} & \multirow{2}{*}{$\begin{array}{l}\text { Drying } \\
\text { method }\end{array}$} & \multicolumn{2}{|c|}{ Seed germination, $\%$} & \multirow{2}{*}{$\begin{array}{l}\text { Yield grain, } \\
\text { t/ha }\end{array}$} \\
\hline & & laboratory & field & \\
\hline \multirow{4}{*}{$\begin{array}{l}\text { Intensive } \\
\text { drying } \\
55^{\circ} \mathrm{C}\end{array}$} & Control * & 98 & 84,5 & 4,67 \\
\hline & Control ** & 96 & 80,9 & 4,54 \\
\hline & Intensive & 96 & 83,1 & 4,6 \\
\hline & $\mathrm{LSD}_{0,05}$ & & 3,8 & 0,16 \\
\hline \multirow{3}{*}{$\begin{array}{l}\text { Recirculation } \\
\text { of heat }\end{array}$} & Control ** & 96 & 82 & 7,2 \\
\hline & Recirculation & 96 & 86 & 7,21 \\
\hline & $\mathrm{LSD}_{0,05}$ & & 2,0 & 0,13 \\
\hline \multirow{3}{*}{$\begin{array}{l}\text { Two-stage } \\
\text { drying }\end{array}$} & Control ** & 99 & 85 & 4,9 \\
\hline & Two-stage & 63 & 52 & 4,08 \\
\hline & $\mathrm{LSD}_{0,05}$ & & 1,5 & 0,15 \\
\hline
\end{tabular}

*natural drying of cobs; **regulated drying method

In general, it has been proved that drying at low temperatures and at higher relative humidity has a positive effect on the thermal cracking prevention [22].

The above energy-saving techniques only partially solved the problem, as traditional fuels (liquid and gaseous) were used, the fuels cost is constantly growing.

We were the first to conduct a study of a new energysaving drying method which uses heat generators for burning plant waste. The new energy-saving complex, consisting of a typical SKP chamber corn dryer and a new TPG heat generator, worked in accordance with the regulated drying regime, i.e. maintained the optimal temperature and relative humidity of the working coolant [23].

The complex was used to dry corn hybrids in cobs with moisture ranging from $17,0-25,0 \%$ to $10,5-11,2 \%$, which was slightly lower than standard (14\%). Over-drying is associated with different moisture of the cobs loaded into the dryer and placed in separate chambers, as their moisture ranged from 3$5 \%$. Therefore, to obtain a uniformly dry grain as a whole in the chamber we had to apply cobs over-drying.

To determine the effect of over-drying, we investigated the thermal cracking of seeds dried on the new unit/complex and under control conditions. It was found that after the control drying the thermal cracking was $0-5 \%$, after drying in the complex $2-5 \%$. Such indicators are much lower as compared to those obtained after the current drying methods and amounted to $25-30 \%$. The effect of drying temperature on 
corn seeds fracture has been proved by other researchers: at $50^{\circ} \mathrm{C}$ the grain micro damage increased to $22 \%$ [24].

In general, we can note the positive effect of the new energy-saving method, which provides a mild temperature regime and ensures the practical absence of thermal damage in the form of cracks (Table 3).

Table 3. Technological properties of corn hybrids seeds dried by different methods.

\begin{tabular}{llllll}
\hline \multirow{2}{*}{ Hybrid } & Drying & \multicolumn{2}{l}{$\begin{array}{l}\text { Moisture } \\
\text { grain, \% }\end{array}$} & $\begin{array}{l}\text { Weight of } \\
\text { 1000 seeds, }\end{array}$ & $\begin{array}{l}\text { Thermal } \\
\text { cracking, \% }\end{array}$ \\
\cline { 2 - 4 } & initial & final & g & \\
\hline \multirow{2}{*}{ Orzhytsia } & Control * & & 12,4 & 222,4 & 1 \\
237 MV & Control ** & 17,0 & 11,2 & 215,0 & 0 \\
& Energy saving & & 10,5 & 226,8 & 5 \\
DN & Control * & & 13,8 & 311,9 & 1 \\
Akvozor & Control ** & 25,0 & 12,4 & 321,0 & 3 \\
& Energy saving & & 11,2 & 317,0 & 4 \\
DB & Control * & & 14,0 & 320,3 & 0 \\
Khotyn & Control ** & 21,5 & 11,4 & 301,6 & 1 \\
& Energy saving & & 10,8 & 315,6 & 2 \\
DN & Control * & & 12,2 & 351,4 & 1 \\
Khortytsia & Control ** & \multirow{2}{*}{18,6} & 10,6 & 345,2 & 5 \\
& Energy saving & & 11,4 & 347,8 & 4 \\
\hline
\end{tabular}

$*$ natural drying; **laboratory drying, $\mathrm{t}=38^{\circ} \mathrm{C}$.

The main criterion for assessing the seed drying quality are indicators of its laboratory and field germination. It is proved that increase of seed heating temperature to $60^{\circ} \mathrm{C}$ and above has a negative effect on laboratory germination [25].

In the experiments, the laboratory germination for all three variants of drying had high values, not lower than the conditional ones. The cold germination results for all methods were approximately the same and within error margin. The largest difference was for the hybrid DB Khotyn by control drying methods.

Field germination for all hybrids and drying methods was at a high level -not less than $80 \%$. For hybrids DB Khotyn, DN Khortytsia and DN Akvozor, the field germination after energy-saving drying was $86-88 \%$. On average, for all studied hybrids, the increase in seeds field germination after energy-saving drying was $2-7 \%$ (Table 4 ).

Table 4. Influence of a new drying method on indicators of laboratory and field germination.

\begin{tabular}{lllll}
\hline \multirow{2}{*}{ Hybrid } & \multirow{2}{*}{ Drying method } & \multicolumn{3}{l}{ Germination,\% } \\
\cline { 3 - 5 } & & laboratory & cold test & field \\
\hline \multirow{3}{*}{ Orzhytsia } & Control * & 98 & 90 & 80 \\
237 MV & Control ** & 95 & 92 & 81 \\
& Energy saving & 95 & 93 & 84 \\
& LSD $_{0,05}$ & 5,5 & 6,0 & 4,6 \\
DN & Control * & 96 & 92 & 81 \\
Khortytsia & Control ** & 98 & 95 & 88 \\
& Energy saving & 99 & 95 & 88 \\
& LSD 0,05 & 4,4 & 4,5 & 6,9 \\
DB & Control * & 99 & 95 & 84 \\
Khotyn & Control ** & 97 & 90 & 82 \\
& Energy saving $^{*}$ & 97 & 91 & 86 \\
DN & LSD $_{0,05}$ & 3,8 & 5,3 & 5,6 \\
Akvozor & Control * & 99 & 90 & 83 \\
& Control $^{* *}$ & 97 & 90 & 86 \\
& Energy saving $^{*}$ & 98 & 92 & 86 \\
& LSD $_{0,05}$ & 2,9 & 3,5 & 4,4 \\
\hline
\end{tabular}

$*$ natural drying; $* *$ laboratory drying, $\mathrm{t}=38^{\circ} \mathrm{C}$.

This proves that the working coolant formed from the biomass combustion had the optimal temperature and relative humidity [23].

Along with field germination, plant growth and development indicators were also determined. Significant effect of the drying method on the growth and development of plants is not observed. Pre-harvest density was 45,9-52,3 thousands of plants per hectare, depending on the hybrid and drying method. The yield of Orzhytsia hybrid $237 \mathrm{MW}$ after drying on an energy-saving complex was slightly higher than the yield of seeds dried in the laboratory (Table 5). On average, for all studied hybrids, the increase in seed yield after energy-saving drying was 0,06-0,63 t/ha.

Table 5. Influence of corn hybrids seeds drying methods on indicators of growth, plants development and productivity.

\begin{tabular}{|c|c|c|c|c|c|}
\hline \multirow{2}{*}{ Hybrid } & \multirow{2}{*}{ Drying method } & \multicolumn{2}{|c|}{ Plant height, cm } & \multirow{2}{*}{$\begin{array}{l}\text { Pre-harvest density, thousands of } \\
\text { plants per hectare }\end{array}$} & \multirow{2}{*}{ Yield grain, $t / h a$} \\
\hline & & 7-8 leaves & in full bloom & & \\
\hline \multirow{4}{*}{ Orzhytsia 237 MV } & Control * & 59,1 & 200,4 & 45,9 & 5,50 \\
\hline & Control ** & 60,7 & 199,7 & 46,5 & 5,40 \\
\hline & Energy saving & 60,3 & 208,3 & 47,8 & 6,03 \\
\hline & $\mathrm{LSD}_{0,05}$ & & & & 0,33 \\
\hline \multirow{4}{*}{ DN Khortytsia } & Control * & 61,9 & 228,0 & 49,7 & 6,89 \\
\hline & Control ** & 61,1 & 226,9 & 49,7 & 6,98 \\
\hline & Energy saving & 60,1 & 218,2 & 52,3 & 7,12 \\
\hline & $\mathrm{LSD}_{0,05}$ & & & & 0,55 \\
\hline \multirow{4}{*}{ DB Khotin } & Control * & 54,1 & 207,1 & 47,2 & 7,96 \\
\hline & Control ** & 57,6 & 207,4 & 53,6 & 8,21 \\
\hline & Energy saving & 57,0 & 204,5 & 51,7 & 8,27 \\
\hline & $\mathrm{LSD}_{0,05}$ & & & & 0,44 \\
\hline \multirow{4}{*}{ DN Akvozor } & Control * & 62,1 & 214,4 & 49,1 & 7,61 \\
\hline & Control ** & 61,9 & 215,9 & 51,7 & 7,80 \\
\hline & Energy saving & 63,2 & 215,2 & 49,7 & 7,79 \\
\hline & $\mathrm{LSD}_{0,05}$ & & & & 0,30 \\
\hline
\end{tabular}

* natural drying; ** laboratory drying, $\mathrm{t}=38^{\circ} \mathrm{C}$. 
The same thing happens at drying the seeds of the parent forms. Seeds dried on the energy-saving complex had high sowing and yielding properties. For the line DK $365 \mathrm{CV}$, the field germination rate for all three variants ranged from 65-69\% (Table 6).

Table 6. Influence of drying methods for corn seeds of parent components on germination and productivity.

\begin{tabular}{|c|c|c|c|c|c|c|}
\hline \multirow{2}{*}{ Hybrid } & \multirow{2}{*}{$\begin{array}{l}\text { Initial grain } \\
\text { moisture, } \%\end{array}$} & \multirow{2}{*}{ Drying method } & \multicolumn{3}{|c|}{ Germination, \% } & \multirow{2}{*}{ Yield grain, $t / h a$} \\
\hline & & & laboratory & cold test & field & \\
\hline \multirow{4}{*}{ Cross $254 \mathrm{M}(\mathrm{S})$} & \multirow{4}{*}{22,4} & Control * & 97 & 83 & 88 & 5,45 \\
\hline & & Control ** & 98 & 79 & 87 & 5,44 \\
\hline & & Energy saving & 97 & 90 & 85 & 5,47 \\
\hline & & $\mathrm{LSD}_{0,05}$ & & & 4,2 & 0,53 \\
\hline \multirow{3}{*}{ Cross $255 \mathrm{M}(\mathrm{S})$} & \multirow{3}{*}{32,1} & Control * & 99 & 95 & 78 & 5,39 \\
\hline & & Control ** & 96 & 94 & 75 & 5,37 \\
\hline & & $\mathrm{LSD}_{0,05}$ & & & 5,3 & 0,68 \\
\hline \multirow{4}{*}{ Cross $266 \mathrm{C}$} & \multirow{4}{*}{18,0} & Control * & 98 & 95 & 88 & 6,86 \\
\hline & & Control ** & 99 & 93 & 85 & 6,93 \\
\hline & & Energy saving & 96 & 91 & 84 & 6,75 \\
\hline & & $\mathrm{LSD}_{0,05}$ & & & 5,4 & 0,51 \\
\hline \multirow{2}{*}{ DK $365 \mathrm{CV}$} & \multirow{2}{*}{30,5} & Control * & 98 & 93 & 67 & 2,76 \\
\hline & & Control ** & 97 & 87 & 69 & 2,85 \\
\hline
\end{tabular}

$*$ natural drying; $* *$ laboratory drying, $\mathrm{t}=38^{\circ} \mathrm{C}$.

\section{Conclusions}

We established energy-saving techniques for corn seeds drying in SKP type chamber dryers; they should include twostage cobs drying with additional drying in grain; return of spent coolant to the drying zone (recirculation); application of maximum allowable cobs heating temperatures. Of the above techniques, the most practical is the reversal and recirculation of the coolant, which reduces fuel consumption by $20-26 \%$, fully preserves the seed quality, does not require significant technical and technological re-equipment of chamber corn dryers.

It is established that when drying corn seed the temperature regime in the dryer is of fundamental importance. A mild regime corresponding to temperature of $38-45^{\circ} \mathrm{C}$ is optimal, and it is possible to obtain quality corn seeds with high indicators.

We determined a fundamentally new method of energy saving based on the replacement of traditional fuels with biomass fuel (corn cobs, wood chips). We tested technological equipment for the new method, it includes a chamber corn dryer and a heat generator for plant waste combustion.

The new method provides a mild temperature and reduced thermal fracturing of the seeds. Due to the mild drying of the studied hybrids (Orzhytsia 237 MV, DB Khotyn, DN Akvozor, DN Khortytsia), their field germination increased by $2-7 \%$, and the yield by $0,06-0,63$ t/ha. No significant negative effect of the new method on sowing and yield properties of parent components seeds of the studied hybrids was revealed.

The new method and technical- technological equipment is recommended for implementation in seed farms engaged in the selection and production of corn hybrids seeds.

In the future, it is planned to study the level of emissions of harmful substances into the atmosphere during the combustion of various types of biofuels at the new energysaving complex, and to determine its impact on the quality of seeds of other cereals crops.

\section{References}

[1] Xu J., Chen W., Qingyue B., Zhongyan L., Zhentao Z. (2020) Study on drying characteristics of corn based on 3D model. International Journal of Food Engineering, 16 (8).

[2] Alejnikov, V. I. (2002). Comprehensive improvement of the drying process in the mine and chamber grain dryers. Scientific works ONAFT, 24, 28-31.

[3] Claumann. C. A., Cancelier. A., Silva, A., Zibetti, A. W., Lopes, T. J., Machado, R. A. (2017). Fitting semi-empirical drying models using a tool based on wavelet neural networks: Modeling a maize drying process. Journal of Food Process Engineering, 41 (1), 1-12.

[4] Suleiman, R., Bern, C. J., Brumm, T. J., Rosentrater, K. A. (2018). Impact of moisture content and maize weevils on maize quality during hermetic and non-hermetic storage. Journal of Stored Products Research, 78, 1-10.

[5] Stankevich G. M., Ovsjannikova L. K. Development of energy-saving technology for drying grain in grain dryers of low productivity. Scientific works ONAFT, 21, 24-26.

[6] Bin L., Chengjie L., Junying H., Changyou L. (2020) Exergoeconomic Analysis of Corn Drying in a Novel Industrial Drying System. Entropy, 22 (6), 689.

[7] Abasi, S., Minael, S. (2014). Effect of Drying Temperature on Mechanical Properties of Dried Corn. Drying Technology An International Journal, 32 (7), 774-780.

[8] Coradi, P. C., Fernandes, C. P., Helmich J. C., Goneli, A. D. (2016). Effects of drying air temperature and grain initial moisture content on soybean quality (Glycine Max (L.) Merrill). Engenharia Agrícola, 36 (5). 
[9] Coradi, P. C., Fernandes, C. P., Peralta, C. C., Pereira, T. L. (2015). Effects of drying and storage conditions in the quality of sunflower seeds. Pap Pesquisa Agropecuaria Pernambucana, 20 (1).

[10] Instruction on the processing of hybrid and varietal corn seeds in factories. (1971). Moskva. 1971. 83.

[11] Stankevych, G. M., Strahova, T. V., Atanazevych, V. I. (1997). Grain drying. Lybid', Kiev, 352.

[12] Kyrpa, M. Ja., Kulyk, V. O. (2016). Energy-saving techniques in corn seed drying technology. Bulletin of the Institute of Agriculture of the steppe zone of the NAAS of Ukraine, 11, 8287.

[13] Kyrpa, N. Ja. (1986). Two-stage drying of corn seeds. Corn breeding and seed production, 174-181.

[14] Fushimi, C., Fukui, K. (2014). Simplification and Energy Saving of Drying Process Based on Self-Heat Recuperation Technology. Drying Technology An International Journal, 32 (6), 667-678.

[15] Zhidko, V. I., Rezchikov, V. A., Ukolov, V. S. (1982). Grain drying and grain dryers. Kolos, Moscow 239.

[16] Snjezhkin, Ju., Pazjuk, V., Petrova, Zh., Vyshnjevs'kyj, V. (2019). Development of energy efficient modes of drying of seeds of grain crops. Scientific Works, 83 (2), 121-127.

[17] Del Campo, B. G., Brumm, T. J., Bern, C. J., Nyendu G. C. (2014). Corn cob dry matter loss in storage as affected by temperature and moisture content. American Society of Agricultural and Biological Engineers, 57 (2), 573-578.
[18] SSTU 4138-2002. 2003. Seeds of agricultural crops. Methods of definition their quality. [Effective since $2004-01-01$ ]. Publish. official. Kyiv: Holding the standard override of Ukraine, 173 p. https://www.twirpx.com/file/2576304/.

[19] Kyrpa, N. Ja. (2004). Methods for assessing the quality and seeding suitability of seeds. Grain storage and processing, 2, 21-22.

[20] Lebid', Je. M., Cykov, V. S., Pashhenko, Ju. M. (2008). Methods of conducting experiments with corn: methodical recommendations. DU IZK NAANU, 27.

[21] Dospehov B. A. (1985). Methods of field experience (with the basics of statistical processing of research results). Agropromizdat, 351.

[22] Shuo W., Bo X., Weijun X., Fenghe W., Pengxiao C., Deyong Y. (2020) Stress simulation and cracking prediction of corn kernels during hot-air drying. Food and Bioproducts Processing. Vol 121, 202-212.

[23] M. Kyrpa, V. Kulyk (2019) New power-saving complex for drying seeds of corn, Visnyk agrarnoi nauky. (97) 4, 60-66.

[24] Peter B., Miroslav M., Ivan R., Pavol F., Adam F., Pawel K., Urszula M.. (2019). The influence of drying temperature and moisture of corn seeds planted on their damage. Agricultural Engineerin, 23 (1), 5-11.

[25] Everson Reis Carvalho, Victor Moss Francischini, Suemar Alexandre Gonçalves Avelar, Júlia Camargos da Costa. (2019). Temperatures and periods of drying delay and quality of corn seeds harvested on the ears. Journal of Seed Science. 41 (3), 336-343. 